IRA-International Journal of Education \& Multidisciplinary Studies

ISSN 2455-2526; Vol.04, Issue 02 (2016)

Pg. no. 323-345

Institute of Research Advances

http://research-advances.org/index.php/IJEMS

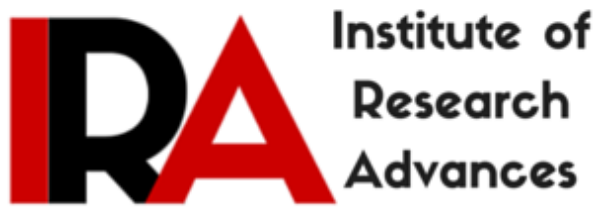

\title{
Perception of Psycho-Social School Environment, Personal Growth Initiative and Fear of Failure among EAMCET Aspirants
}

\author{
Nandini Sanyal ${ }^{1 \#}$, Tina Fernandes ${ }^{2}$, Zaina Hazari $^{3}$ \\ St. Francis College for Women \\ ${ }^{1}$ Asst. Prof., Dept. of Psychology, St. Francis College for Women, \\ Begumpet, Hyderabad - 500016, India. \\ ${ }^{2}$ Head, Dept. of Psychology, St. Francis College for Women, \\ Begumpet, Hyderabad - 500016, India. \\ ${ }^{3}$ Post Graduate Student, St. Francis College for Women, Begumpet, \\ Hyderabad - 500016, India.
}

\#Corresponding author: Nandini Sanyal, Asst. Prof., Dept. of Psychology, St.

Francis College for Women, Begumpet, Hyderabad - 500016, India.

Type of Review: Peer Reviewed

DOI: http://dx.doi.org/10.21013/jems.v4.n2.p11

\section{How to cite this paper:}

Sanyal, N., Fernandes, T., \& Hazari, Z. (2016). Perception of Psycho-Social School Environment, Personal Growth Initiative and Fear of Failure among EAMCET Aspirants. IRA International Journal of Education and Multidisciplinary Studies (ISSN 2455-2526), 4(2), 323-345. doi:http://dx.doi.org/10.21013/jems.v4.n2.p11

(C) Institute of Research Advances

\section{(c)) EY-NO}

This work is licensed under a Creative Commons Attribution-Non Commercial 4.0 International License subject to proper citation to the publication source of the work.

Disclaimer: The scholarly papers as reviewed and published by the Institute of Research Advances (IRA) are the views and opinions of their respective authors and are not the views or opinions of the IRA. The IRA disclaims of any harm or loss caused due to the published content to any party. 


\section{ABSTRACT}

The objective of the present study is to investigate whether there is a relationship between perception of psycho-social school environment, personal growth initiative and fear of failure in intermediate students. The study also aimed to observe whether there are gender differences between students going to colleges (viz. with EAMCET coaching and without EAMCET coaching) in terms of psycho-social school environment, personal growth initiative and fear of failure in intermediate students. The School Environment Inventory (Misra, 1984), the Personal Growth Initiative Scale-II (Robitschek et al., 2012) and the Performance Failure Appraisal Inventory (Conroy et. al., 2002) were administered on 300 intermediate students (150 boys and 150 girls) selected through a non-probability purposive sampling technique to measure the perception of psycho-social school environment, personal growth initiative and fear of failure respectively. The results indicated significant gender differences between the students going to colleges with coaching and the students going to colleges without coaching with respect to perception of psycho-social school environment and personal growth initiative $(p<0.05)$. However, no significant gender differences were observed in fear of failure and its dimensions ( $p>0.05)$. Among students going to colleges with coaching negative correlations were observed between rejection, fear of experiencing shame and embarrassment and personal growth initiative, moreover in this group, creative stimulation, cognitive encouragement and permissiveness $(p<0.05)$ were positively correlated with using resources and negatively correlated with fears of important others losing interest $(p<0.05)$. Also personal growth initiative was positively correlated with fears of upsetting important others and cognitive encouragement $(p<0.05)$ in students going to colleges without coaching. The present study reiterates that perception of school environment by students is of paramount importance in promoting or hindering the student's personal growth initiative and subsequently their fear of failure.

Key words: intermediate students, coaching, perception of school environment, personal growth initiative, fear of failure

\section{INTRODUCTION}

Beginning in the early 1990s and burgeoning in the first half decade of the 21st century, a new vision and vocabulary for discussing young people has emerged. The new vocabulary emphasizes the idea that every young person has the potential for successful, healthy development and that all youth possess the capacity for positive development (Lerner et al., 2005).

In modern India while adolescence is a comparatively new term, the word youth is better known, particularly at the national and policy making level (Singh, 1977). The adolescent years are filled with many changes, making it a psychologically intriguing stage of development. The adolescent experiences rapid maturational changes, shifting societal demands, conflicting role demands, increasingly complex social relations, and new educational expectations (Wigfield, Byrnes \& Eccles, 2006). Cobb (1995) defines adolescence as "a period in life that begins with biological maturation, during which individuals must accomplish certain developmental tasks, and that ends when they achieve a self-sufficient state of adulthood as defined by society".

Schools potentially can provide early adolescents with opportunities to develop their intellectual capacities, to experience a sense of competence and belonging, and to interact with supportive, nonparental adults. (Eccles \& Midgley, 1989). The study by Verma, Sharma and Larson (2002) examines the influence of school demands and conclude that these adolescents were found to spend one third of their waking time in school-related activities.

The concept that a person's perceptions of the environment had an effect on behaviour was promoted over 70 years ago (Lewin, 1935). Learning environment research has established strong 
relationships between an individual's perception of learning environment and his performance within that environment (Walberg, 1991).

According to Sagar and Kaplan (1972), next to family, the school is the most important experience in the process of child development. When the child enters the school arena, he or she is presented with new opportunities in terms of socialization and cognitive development. These opportunities are provided in different measures in different schools and may have a direct impact on the cognitive and the affective behaviours in students.

According to Wubbels (2005) it is vital for improving student learning to influence student's perceptions of the learning environment. The school environment, as it applies to the educational setting, refers to the atmosphere, the tone, the ambience or climate that pervades the setting that focuses on human behaviour in origin or outcome (Dorman \& Fraser, 2009). Whereas, the psychosocial school environment encompasses the attitudes, feelings, and values of students and staff. Physical and psychological safety, positive interpersonal relationships, recognition of the needs and success of the individual, and support for learning are all part of the psychosocial environment (Sharma, 2011).

The term psychological environment here emphasizes the meaning of the environment to the individual that is being considered here. In this case, it is the student's perceptions of the school environment and their reaction to those perceptions that are of importance (Maehr, 1991).

A research study conducted by Haapasalo, Välimaa and Kannas (2010) concluded that school engagement, school strain, and teacher-student relations were found to be the most influential predictors in the psychosocial school environment regarding perceived school performance.

The perception of the psychosocial school environment can be understood with six dimensions. The creative stimulation can be defined as the teacher's conducting activities to provide conditions and opportunities to stimulate creative thinking (Misra, 1984).

The cognitive encouragement is defined as the teacher's behaviour to stimulate cognitive development of student by encouraging his actions or behaviours (Misra, 1984). Teachers provide personal and instructional supports meant to facilitate the developing sense of student autonomy

Permissiveness is defined as the school climate in which students are provided opportunities to express their views freely and act according to their desires with no interruption from teachers (Misra, 1984).

According to Misra (1984), acceptance implies to a measure of teacher's unconditional love, recognizing that students have the right to express feelings, to uniqueness and to be autonomous individuals. Teachers accept the feelings of students in a non-threatening manner. At a time when adolescents are particularly in need of supportive relationships with adults outside the home, the quality of relationships with teachers is less than optimal (Midgley, Feldlaufer \& Eccles, 1989).

Rejection is defined as the school climate in which the teachers do not accord recognition to student's rights to deviate, act freely and be autonomous persons (Misra, 1984).

Control is defined as the autocratic atmosphere of the school in which several restrictions are imposed on students to discipline them (Misra, 1984). Students attending schools exhibit discipline problems such as disruptive classroom behaviour, vandalism, bullying, and violence. Luiselli, Putnam, Handler and Feinberg (2005) concluded that establishing effective discipline practices is critical to ensure academic success and to provide a safe learning environment. 
From a social cognitive perspective (Bandura, 2001), people tend to react to experiences as they subjectively perceive them, not necessarily to how the experiences are objective. According to Walberg (1991) Learning environment research has established strong relationships between an individual's perception of learning environment and his/her performance within that environment.

Studies on schools and other work organisations show that a high level of participation and influence enhances the commitment of students and/or workers and leads to greater satisfaction in the workplace (Selberg 2001). Moreover research findings also suggest that physical education is a promising intervention to address improving overall adolescent physical activity within the school setting (Durant et al., 2009).

Personal growth is a change within a person that is cognitive, behavioural or affective (Prochaska \& Diclemente, 1986). Generally, this self change is thought of as positive, with movement in the direction of being "more complete and fully functioning" at least from the perspective of the person who is changing.

Personal Growth Initiative is an active, intentional engagement in the process of personal growth and in changing and developing as a person (Robitschek, 1998). PGI includes cognitive components, such as knowing how to change and believing that change is possible, and behavioral components, such as taking the initiative to actually enact the change process. It is as intentional involvement in changing and developing as a person (Robitschek, 1998).

According to Sharma and Rani (2013) Personal Growth Initiative is an acquired skill set for selfimprovement across life domains. It is comprised of four components Readiness for Change which they defined as the ability to assess one's own psychological preparedness to engage in personal growth processes. Planfulness is defined as the ability to be strategic and organized in self-change efforts. Using Resources which is the ability to identify and access resources external to the self, such as other people and materials and Intentional Behaviour which they defined as the actual follow-through, or doing of selfchange plans and behaviours (Sharma \& Rani, 2013). These four components operate synergistically, rather than sequentially, to optimize personal growth (Robitschek et al., 2009).

The results of a research study suggest that college students who are engaging in more intentional self improvement (i.e., have relatively high levels of PGI), in comparison with their low-PGI peers, accept themselves more, have better relationships with others, see more purpose in life, perceive more control and mastery over their environment, and have a greater sense of autonomy or self-direction regarding their lives and daily choices. Similarly, they have a greater feeling of connection to their community, more understanding of the social world around them, a greater sense of contributing to their communities, a forward-looking perspective on society, and a generally favourable view of the people in their world. They also report feeling happier, having greater life satisfaction, and overall, having more positive feelings (Robitschek \& Keyes, 2009).

Fear of failure is defined as a dispositional tendency to avoid failure in achievement settings, because the humiliation and embarrassment of failure is perceived to be overwhelming (Elliott \& Thrash, 2004). Depending on the consequences of the failure and the dispositional tendencies of the individual involved, failure may be seen as an opportunity for growth and development (Axelton,1998; Diller, 1995). While individuals can benefit from failure, for some people, the fear of failure is so threatening and anxiety producing, that any evaluative situation is cause for distress (Covington, 1984).

Conroy et al. (2002) proposed a five beliefs model about the consequences of failure that are associated with threat appraisal and feared. To measure these beliefs, Conroy and colleagues developed the Performance Failure Appraisal Inventory (PFAI; Conroy et. al., 2002) which differentiates five fears 
of failure: fear of experiencing shame and embarrassment, fear of devaluing one's self-estimate, fear of having an uncertain future, fear of important others losing interest and fear of upsetting important other.

Fear of failure may be construed as a self-evaluative framework that influences how the individual defines, orients to, and experiences failure in achievement situations (Heckhausen, 1991). A research study investigated the relationship between fear of failure, disorganization, and affective wellbeing while preparing for a college exam and concluded that fear of failure negatively predicted change in affective well-being. The affective well-being in turn predicted change in disorganization during exam preparation and exam performance (Berger \& Freund, 2012).

In India, to study 10 classes the student must join a school which is recognized by state board or CBSE or ICSE and must get through. In preparing for Intermediate Public Examination (I.P.E), textual matter rather than objective type is important and teachers guide accordingly and students study accordingly whereas preparing for the EAMCET, concept as well as point wise textual matter is important for student and teacher guides accordingly (Rao et al., 2009)

Over the years there has been a tremendous increase in the number of coaching centres for the preparation of the EAMCET examination. According to Kousalya, Ravindranath and Vizayakumar (2006) special coaching institutions which are interested in making quick money organize coaching classes in a residential mode and render students to restless reading rather than studying and understanding the concepts.

According to research conducted by Kenny and Faunce (2004) senior-level students who enjoyed their coaching performed better on some academic measures than did coached students who did not enjoy their coaching. Enjoyment may be an index of motivation, interest or volition because many students do not attend coaching voluntarily but, rather, at their parent's behest. They further reiterated that the extravagant claims made by coaching colleges for improving academic achievement are unwarranted.

Student's perceptions of their educational environment are a useful basis for modifying and improving the quality of educational environment. One of the most important findings of educational research is that meaning orientation to learning is positively associated with student's perception of the learning environment. More importance should be given to the perceptions of students to improve the educational environment as perceptions are associated positively with learning outcome, learning approach and attitude to studying. Positive attitudes and deep approach are linked with academic progress (Mayya \& Roff, 2004). In this context, the research questions are formulated as follows:

\section{Research Questions}

1. Is there a role of type of college (viz. with EAMCET coaching and without EAMCET coaching) and gender on perception of psycho-social school environment measured in terms of its 6 dimensions (viz., Creative stimulation, cognitive encouragement, acceptance, permissiveness, rejection and control), Personal growth initiative and its 4 dimensions (viz., Readiness for change, planfulness, using resources and intentional behaviour) and Fear of failure and its 5 dimensions (viz., Fears of Experiencing Shame and Embarrassment, Fears-of Devaluing One's Self-Estimate, Fears of Having an Uncertain Future, Fears of Important Others Losing Interest and Fears of Upsetting Important Others) in intermediate students?

2. Is there a relationship between perception of psycho-social school environment measured in terms of its 6 dimensions (viz. Creative stimulation, cognitive encouragement, acceptance, permissiveness, rejection and control), Personal growth initiative (and its 4 dimensions viz. Readiness for change, planfulness, using resources and intentional behaviour) and Fear of failure (and its 5 dimensions viz. Fears of Experiencing Shame and Embarrassment, Fears-of Devaluing One's Self-Estimate, Fears of Having an Uncertain Future, Fears of Important Others Losing 
Interest and Fears of Upsetting Important Others) in intermediate students (boys and girls) going to colleges with and without EAMCET coaching?

\section{METHOD}

\section{Research design}

The present study adopts a between groups design to determine whether there are any gender differences between intermediate students (boys and girls) going to colleges with EAMCET coaching and without EAMCET coaching with respect to perception of psycho-social school environment measured in terms of its 6 dimensions (viz., creative stimulation, cognitive encouragement, acceptance, permissiveness, rejection and control), personal growth initiative and its 4 dimensions (viz., readiness for change, planfulness, using resources and intentional behaviour) and fear of failure and its 5 dimensions (viz., fears of experiencing shame and embarrassment, fears-of devaluing one's self-estimate, fears of having an uncertain future, fears of important others losing interest and fears of upsetting important others). The present study also adopts a correlational design to determine whether there is a relationship between the perception of psycho-social school environment, Personal growth initiative and fear of failure in intermediate students (boys and girls) with and without EAMCET coaching.

\section{Sample}

A non-probability purposive sampling technique was used to select 300 second year intermediate students (boys and girls) who were preparing for EAMCET. Among them 150 intermediate students (75 boys and 75 girls) went to colleges with EAMCET coaching and 150 intermediate students ( 75 boys and 75 girls) went to colleges without EAMCET coaching. In the second group, intermediate students who didn't go to colleges with EAMCET coaching but were attending tutorials outside college were selected. Students who had scored $80 \%$ and above in their first intermediate public examination (IPE) were considered for the study.

\section{Instruments}

The Study employs the following four instruments

\section{- Information Schedule}

The participants were asked to fill in a demographic sheet which included their general demographic details like age, sex, gender, state of residence, education, family type and other such details. The demographic sheet also included demographic details specific to the study like the colleges the students attended whether it was with EAMCET coaching or without EAMCET coaching.

\section{- The School Environment Inventory (SEI)}

The School Environment Inventory (SEI) by Misra (1984) is an instrument designed to measure the psycho-social climate of schools as perceived by the pupils. It provides a measure of the quality and quantity of the cognitive, emotional and social support that has been available to the students during their school life in terms of teacher-pupil interactions. SEI has 70 items belonging to six dimensions of the school environment. The dimensions are creative stimulation, cognitive encouragement, permissiveness, acceptance, rejection and control.

The instrument required pupils to tell the frequency with which a particular teacher pupil interaction behaviour is expressed in his or her school by marking on the options 'Always', 'Often', 'Sometimes', 'Rarely' and 'Never'. The split half reliability of the dimensions creative stimulation, cognitive encouragement, permissiveness, acceptance, rejection and control are $0.919,0.797,0.823,0.673,0.781$ and 0.762 respectively.

\section{- The Personal Growth Initiative Scale - II (PGAI-II)}

The Personal Growth Initiative Scale -II by Robitschek et al. (2012), is a revised multidimensional measure of the complex processes of personal growth initiative, which can be described as a person's active and intentional involvement in changing and developing as a person. The Personal Growth Initiative Scale-II (PGIS-II) has 16 items on 6 point likert scale ranging from disagree strongly $(0)$ to agree strongly(5). The Personal Growth Initiative Scale-II (PGIS-II) includes 4 dimensions which are readiness 
for change, planfulness, using resources, and intentional behaviour. The test-retest reliability is 0.74 and the internal consistency is $0.78-0.90$. It has a strong internal consistency for the dimensions, concurrent and discriminant validity.

- The Performance Failure Appraisal Inventory (PFAI)

The Performance Failure Appraisal Inventory (PFAI; Conroy et al., 2002) was used to assess fear of failure. This 25-item measure yields scores for five first order beliefs about aversive consequences of failing and one higher-order factor representing general FF. The dimensions are fears of experiencing shame and embarrassment, fears-of devaluing one's self-estimate, fears of having an uncertain future, fears of important others losing interest and fears of upsetting important others. Participants were asked to think of how often they believed each statement was true in their significant motor performances. Responses were made on a scale ranging from do not believe at all (-2) to believe all the time (2). PFAI scores have demonstrated sound psychometric properties, including factorial invariance across groups and over time, internal consistency, external validity, and predictive validity. Scores have also exhibited evidence of differential stability (i.e., test-retest reliability 0.80), and latent mean stability (Conroy et al., 2003).

\section{Procedure}

After selecting the measures, the potential colleges were identified and approached. Permission was asked from the colleges to conduct the study. Once permission was granted the students in the colleges were approached and rapport was established. The students were first briefed about the study and the informed consent was given to them. Those who consented were provided with a Demographic Sheet and were asked to fill it. The students who met the criteria of the study were given the questionnaires to be filled. Written and oral instructions were given to them and they were asked to seek clarifications for any doubts. They were informed that there is no time limit, however, it will take $40-45$ minutes to be fill the questionnaires. The Participants answered the Questionnaires. The collected data was later analyzed using descriptive and inferential statistics and conclusions were drawn.

\section{RESULTS}

Table 1 - Results of Two-Way ANOVA and descriptive statistics with Perception of Psycho-social school environment in terms of its 6 dimensions; Personal growth initiative and its 4 dimensions and Fear of failure and its 5 dimensions in intermediate students (boys and girls) going to colleges with and without EAMCET coaching $(n=300)$. 


\begin{tabular}{|c|c|c|c|c|c|c|c|}
\hline \multirow[b]{2}{*}{ Variables } & \multicolumn{2}{|c|}{ Type of College } & \multicolumn{4}{|c|}{ Gender of the student } & \multirow{2}{*}{$\begin{array}{c}\text { Interaction } \\
\text { effect } \\
\text { (Gender * } \\
\text { coaching) }\end{array}$} \\
\hline & $\begin{array}{c}\text { With Coaching } \\
\text { Mean } \\
(\mathrm{SD}) \\
\end{array}$ & $\begin{array}{c}\text { Without Coaching } \\
\text { Mean } \\
\text { (SD) } \\
\end{array}$ & $\mathrm{F}$ & $\begin{array}{l}\text { Boys } \\
\text { Mean } \\
(\mathrm{SD}) \\
\end{array}$ & $\begin{array}{l}\text { Girls } \\
\text { Mean } \\
(\mathrm{SD}) \\
\end{array}$ & $\mathrm{F}$ & \\
\hline $\begin{array}{c}\text { Creative } \\
\text { stimulation }\end{array}$ & $\begin{array}{l}47.246 \\
(14.704)\end{array}$ & $\begin{array}{l}53.606 \\
(9.695)\end{array}$ & $21.710^{* *}$ & $\begin{array}{c}48.1 \\
(12.495)\end{array}$ & $\begin{array}{l}52.753 \\
(12.788)\end{array}$ & $11.063^{* *}$ & 3.013 \\
\hline $\begin{array}{c}\text { Cognitive } \\
\text { encouragement }\end{array}$ & $\begin{array}{c}26.66 \\
(8.132)\end{array}$ & $\begin{array}{l}31.766 \\
(6.495)\end{array}$ & $43.455^{* *}$ & $\begin{array}{l}26.253 \\
(7.985)\end{array}$ & $\begin{array}{l}32.173 \\
(6.328)\end{array}$ & $58.345^{* *}$ & 0.315 \\
\hline & 22.12 & 26.813 & $38.153^{* *}$ & 23.273 & 25.66 & $9.546 * *$ & $6.452^{*}$ \\
\hline Permissiveness & $\begin{array}{l}(8.026) \\
21.74\end{array}$ & $\begin{array}{l}(5.591) \\
24.913\end{array}$ & $18.248 * *$ & $\begin{array}{c}(7.538) \\
23.18\end{array}$ & $\begin{array}{l}(6.861) \\
23.473\end{array}$ & 0.161 & 2.214 \\
\hline Acceptance & (7.314) & (5.914) & & $(7.25)$ & $(6.399)$ & & \\
\hline Rejection & $\begin{array}{l}20.673 \\
(7.136)\end{array}$ & $\begin{array}{c}16.42 \\
(6.788)\end{array}$ & $30.391 * *$ & $\begin{array}{l}21.046 \\
(6.502)\end{array}$ & $\begin{array}{l}16.046 \\
(7.159)\end{array}$ & $44.383^{* *}$ & 0.25 \\
\hline Control & $\begin{array}{l}24.553 \\
(5.203)\end{array}$ & $\begin{array}{c}25.66 \\
(4.495)\end{array}$ & $3.967^{*}$ & $\begin{array}{l}24.48 \\
(4.955)\end{array}$ & $\begin{array}{l}25.733 \\
(4.749)\end{array}$ & $5.112 *$ & $5.261^{*}$ \\
\hline $\begin{array}{l}\text { Readiness for } \\
\text { change }\end{array}$ & $\begin{array}{c}3.49 \\
(1.079)\end{array}$ & $\begin{array}{l}3.366 \\
(1.01)\end{array}$ & 0.994 & $\begin{array}{l}3.203 \\
(1.111)\end{array}$ & $\begin{array}{c}3.653 \\
(0.926)\end{array}$ & $14.417^{* *}$ & 0 \\
\hline & 3.156 & 3.47 & $6.812^{* *}$ & 3.1 & 3.526 & $13.082^{* *}$ & 3.209 \\
\hline Planfulness & $(1.208)$ & $(0.854)$ & & (1.164) & $(0.891)$ & & \\
\hline $\begin{array}{l}\text { Using } \\
\text { resources }\end{array}$ & $\begin{array}{c}3.12 \\
(1.116)\end{array}$ & $\begin{array}{c}3.397 \\
(1)\end{array}$ & $5.770^{*}$ & $\begin{array}{c}3.02 \\
(1.054)\end{array}$ & $\begin{array}{c}3.497 \\
(1.029)\end{array}$ & $16.279 * *$ & $5.954^{*}$ \\
\hline $\begin{array}{l}\text { Intentional } \\
\text { behavior }\end{array}$ & $\begin{array}{c}3.463 \\
(1.216)\end{array}$ & $\begin{array}{l}3.85 \\
(0.92)\end{array}$ & $9.832^{* *}$ & $\begin{array}{c}3.46 \\
(1.195)\end{array}$ & $\begin{array}{c}3.853 \\
(0.946)\end{array}$ & $10.368^{* *}$ & 0.988 \\
\hline $\begin{array}{l}\text { Personal growth } \\
\text { initiative }\end{array}$ & $\begin{array}{l}3.307 \\
(0.966)\end{array}$ & $\begin{array}{l}3.521 \\
(0.747)\end{array}$ & $4.967^{*}$ & $\begin{array}{l}3.195 \\
(0.923)\end{array}$ & $\begin{array}{c}3.632 \\
(0.753)\end{array}$ & $20.574^{* *}$ & 2.588 \\
\hline $\begin{array}{l}\text { Fears of } \\
\text { experiencing } \\
\text { shame and } \\
\text { embarrasment }\end{array}$ & $\begin{array}{l}(-) 0.172 \\
(0.801)\end{array}$ & $\begin{array}{l}(-) 0.148 \\
(0.656)\end{array}$ & 0.048 & $\begin{array}{l}(-) 0.124 \\
(0.703)\end{array}$ & $\begin{array}{l}(-) 0.196 \\
(0.758)\end{array}$ & 0.77 & $5.832^{*}$ \\
\hline $\begin{array}{c}\text { Fears of } \\
\text { devaluing one's } \\
\text { self-estimate }\end{array}$ & $\begin{array}{l}(-) 0.818 \\
(0.709)\end{array}$ & $\begin{array}{l}(-) 0.683 \\
(0.823)\end{array}$ & 2.001 & $\begin{array}{l}(-) 0.711 \\
(0.775)\end{array}$ & $\begin{array}{l}(-) 0.790 \\
(0.764)\end{array}$ & 0.806 & $6.570^{*}$ \\
\hline $\begin{array}{l}\text { Fears of having } \\
\text { an uncertain } \\
\text { future }\end{array}$ & $\begin{array}{c}(-) 0.0783 \\
(0.863)\end{array}$ & $\begin{array}{l}(-) 0.101 \\
(0.822) \\
\end{array}$ & 1.74 & $\begin{array}{l}(-) 0.163 \\
(0.826)\end{array}$ & $\begin{array}{l}(-) 0.016 \\
(0.853)\end{array}$ & 2.254 & $4.588^{*}$ \\
\hline
\end{tabular}




\begin{tabular}{|c|c|c|c|c|c|c|c|}
\hline \multirow[b]{2}{*}{ Variables } & \multicolumn{2}{|c|}{ Type of College } & \multicolumn{4}{|c|}{ Gender of the student } & \multirow{2}{*}{$\begin{array}{c}\text { Interaction } \\
\text { effect } \\
\text { (Gender * } \\
\text { coaching) }\end{array}$} \\
\hline & $\begin{array}{c}\text { With Coaching } \\
\text { Mean } \\
(\mathrm{SD})\end{array}$ & $\begin{array}{c}\text { Without Coaching } \\
\text { Mean } \\
(\mathrm{SD}) \\
\end{array}$ & $F$ & $\begin{array}{l}\text { Boys } \\
\text { Mean } \\
(\mathrm{SD}) \\
\end{array}$ & $\begin{array}{l}\text { Girls } \\
\text { Mean } \\
(\mathrm{SD}) \\
\end{array}$ & $F$ & \\
\hline $\begin{array}{c}\text { Fears of } \\
\text { important others }\end{array}$ & $(-) 0.644$ & $(-) 0.534$ & 1.17 & $(-) 0.496$ & $(-) 0.682$ & 3.417 & 1.964 \\
\hline losing interest & $(0.843)$ & $(0.899)$ & & $(0.851)$ & $(0.884)$ & & \\
\hline $\begin{array}{l}\text { Fears of } \\
\text { upsetting }\end{array}$ & $(-) 0.186$ & $(-) 0.360$ & 3.319 & $(-) 0.289$ & $(-) 0.257$ & 0.107 & 3.007 \\
\hline important others & $(0.783)$ & $(0.797)$ & & $(0.7791)$ & $(0.811)$ & & \\
\hline $\begin{array}{l}\text { General fear of } \\
\text { failure }\end{array}$ & $\begin{array}{r}(-) 0.379 \\
(0.515) \\
\end{array}$ & $\begin{array}{r}(-) 0.365 \\
(0.506) \\
\end{array}$ & 0.023 & $\begin{array}{r}(-) 0.356 \\
(0.509) \\
\end{array}$ & $\begin{array}{l}(-) 0.388 \\
(0.512) \\
\end{array}$ & 0.307 & $4.947^{*}$ \\
\hline
\end{tabular}

Table 1 indicated that there was a significant difference between the students going to colleges with EAMCET coaching and the students going to colleges without EAMCET coaching with respect to the creative stimulation dimension of perception of psycho-social school environment $(\mathrm{F}=21.710, \mathrm{p}<$ 0.01). Similarly, the results also indicated that there was a significant difference between the boys and girls with respect to the creative stimulation dimension perception of psycho-social school environment $(\mathrm{F}=11.063, \mathrm{p}<0.01)$. As was evident from the mean scores, the students going to colleges without EAMCET coaching scored higher $(M=53.606)$ than the students going to colleges with EAMCET coaching $(M=47.246)$. In other words students going to colleges without EAMCET coaching especially the girls $(M=52.753)$ viewed their teacher's as providing opportunities to stimulate creative thinking than the boys $(\mathrm{M}=48.1)$.

Moreover table 1 also indicated that there was a significant difference between the students going to colleges with EAMCET coaching and the students going to colleges without EAMCET coaching with respect to the cognitive encouragement dimension of perception of psycho-social school environment $(\mathrm{F}=$ $43.455, \mathrm{p}<0.01)$. Similarly the results also indicated that there was a significant difference between the boys and girls with respect to the cognitive encouragement dimension of perception of psycho-social school environment $(\mathrm{F}=58.345, \mathrm{p}<0.01)$. As was evident from the mean scores, the students going to colleges without EAMCET coaching scored higher $(M=31.766)$ than the students going to colleges with EAMCET coaching $(M=26.66)$. In other words, students going to colleges without EAMCET coaching especially the girls $(M=32.173)$ viewed their teacher's behaviour as stimulating cognitive development of students by encouraging their actions or behaviours than the boys $(M=26.253)$.

Furthermore table 1 reveals that there was a significant difference between the students going to colleges with EAMCET coaching and the students going to colleges without EAMCET coaching with respect to the permissiveness dimension of perception of psycho-social school environment $(\mathrm{F}=38.153$, $\mathrm{p}<0.01)$. Similarly the results also indicated that there was a significant difference between the boys and girls with respect to the permissiveness dimension of perception of psycho-social school environment $(\mathrm{F}=$ 9.546, $\mathrm{p}<0.01)$. As was evident from the mean scores, the students going to colleges without EAMCET coaching scored higher $(\mathrm{M}=26.813)$ than the students going to colleges with EAMCET coaching $(\mathrm{M}=$ 22.12). In other words students going to colleges without EAMCET coaching especially the girls (M= 25.66) viewed their college as providing opportunities to express their views freely and act according to their desires without any interruptions from the teachers than the boys $(M=23.273)$. 
Table 1 shows that there was a significant difference between the students going to colleges with EAMCET coaching and the students going to colleges without EAMCET coaching with respect to the acceptance dimension of perception of psycho-social school environment $(\mathrm{F}=18.248, \mathrm{p}<0.01)$. As was evident from the mean scores, the students going to colleges without EAMCET coaching scored higher $(M=24.913)$ than the students going to colleges with EAMCET coaching $(M=21.74)$. In other words students going to colleges without EAMCET coaching especially the girls $(M=23.473)$ viewed their teachers as accepting the feelings of students in a non-threatening manner than the boys $(\mathrm{M}=23.18)$.

The results in table 1 also indicated that there was a significant difference between the students going to colleges with EAMCET coaching and the students going to colleges without EAMCET coaching with respect to the rejection dimension of perception of psycho-social school environment $(\mathrm{F}=30.391, \mathrm{p}<$ 0.01). Similarly the results also indicated that there was a significant difference between the boys and girls with respect to the rejection dimension of school environment inventory $(F=44.383, p<0.01)$. As was evident from the mean scores, the students going to colleges with EAMCET coaching scored higher $(M=20.673)$ than the students going to colleges without EAMCET coaching $(M=16.42)$. In other words students going to colleges with EAMCET coaching especially the boys $(M=21.046)$ viewed their college in which the teachers do not accord recognition to student's right to deviate, act freely and be autonomous persons than the girls $(M=16.046)$.

Moreover table 1 also shows that there was a significant difference between the students going to colleges with EAMCET coaching and the students going to colleges without EAMCET coaching with respect to the control dimension of perception of psycho-social school environment $(F=3.967, p<0.05)$. Similarly the results also indicated that there was a significant difference between the boys and girls with respect to the control dimension of perception of psycho-social school environment $(\mathrm{F}=5.112, \mathrm{p}<0.05)$. As was evident from the mean scores, the students going to colleges without EAMCET coaching scored higher $(M=25.66)$ than the students going to colleges with EAMCET coaching $(M=24.553)$. In other words students going to colleges without EAMCET coaching especially the girls $(M=25.733)$ viewed their college as imposing several restrictions on the students to dwascipline them than the boys $(\mathrm{M}=$ 24.48).

Furthermore table 1 also reveals that there was a significant difference between the boys and girls going to colleges with and without EAMCET coaching with respect to the readiness for change dimension of personal growth initiative $(\mathrm{F}=14.417, \mathrm{p}<0.01)$. As in evident from the mean scores, the students going to colleges with EAMCET coaching scored higher $(\mathrm{M}=3.49)$ than the students going to colleges without EAMCET coaching $(\mathrm{M}=3.366)$. In other words the students going to colleges with EAMCET coaching especially the girls $(M=3.653)$ showed likelihood towards the ability to assess one's own psychological preparedness to engage in personal growth processes than the boys $(M=3.203)$.

Table 1 indicates that there was a significant difference between the students going to colleges with EAMCET coaching and the students going to colleges without EAMCET coaching with respect to the planfulness dimension of personal growth initiative $(\mathrm{F}=6.812, \mathrm{p}<0.01)$. Similarly the results also indicated that there was a significant difference between the boys and girls with respect to the planfulness dimension of personal growth initiative $(\mathrm{F}=13.082, \mathrm{p}<0.01)$. As was evident from the mean scores, the students going to colleges without EAMCET coaching scored higher $(\mathrm{M}=3.470)$ than the students going to colleges with EAMCET coaching $(\mathrm{M}=3.156)$. In other words students going to colleges without EAMCET coaching especially the girls $(M=3.526)$ showed likelihood towards the ability to be strategic and organized in self-change efforts than the boys $(M=3.1)$.

Table 1 also revealed that there was a significant difference between the students going to colleges with EAMCET coaching and the students going to colleges without EAMCET coaching with respect to the using resources dimension of personal growth initiative $(F=5.770, p<0.05)$. Similarly the 
results also indicated that there was a significant difference between the boys and girls with respect to the using resources dimension of personal growth initiative $(\mathrm{F}=16.279, \mathrm{p}<0.01)$. As was evident from the mean scores, the students going to colleges without EAMCET coaching scored higher $(\mathrm{M}=3.397)$ than the students going to colleges with EAMCET coaching $(M=3.12)$. In other words students going to colleges without EAMCET coaching especially the girls $(\mathrm{M}=3.497)$ showed likelihood towards the ability to identify and access resources external to the self, such as other people and materials than the boys $(\mathrm{M}=3.02)$.

Moreover table 1 shows that there was a significant difference between the students going to colleges with EAMCET coaching and the students going to colleges without EAMCET coaching with respect to the intentional behaviour dimension of personal growth initiative $(F=9.832, p<0.01)$. Similarly the results also indicated that there was a significant difference between the boys and girls with respect to the intentional behaviour dimension of personal growth initiative $(\mathrm{F}=10.368, \mathrm{p}<0.01)$. As was evident from the mean scores, the students going to colleges without EAMCET coaching scored higher $(\mathrm{M}=3.85)$ than the students going to colleges with EAMCET coaching $(M=3.463)$. In other words students going to colleges without EAMCET coaching especially the girls $(\mathrm{M}=3.853)$ showed likelihood towards doing of self-change plans and behaviours than the boys $(\mathrm{M}=3.46)$.

Furthermore table 1 also shows that there was a significant difference between the students going to colleges with EAMCET coaching and the students going to colleges without EAMCET coaching with respect to the dimension of personal growth initiative $(\mathrm{F}=4.967, \mathrm{p}<0.05)$. Similarly the results also indicated that there was a significant difference between the boys and girls with respect to the using resources dimension of personal growth initiative $(\mathrm{F}=20.574, \mathrm{p}<0.01)$. As was evident from the mean scores, the students going to colleges without EAMCET coaching scored higher $(\mathrm{M}=3.521)$ than the students going to colleges with EAMCET coaching $(\mathrm{M}=3.307)$. In other words students going to colleges without EAMCET coaching especially the girls $(M=3.632)$ showed active and intentional involvement in changing and developing as a person than the boys $(\mathrm{M}=3.195)$.

Table 1 also indicated significant interaction between the type of college (with and without EAMCET coaching) and gender of the student (boys and girls) with respect to permissiveness dimension of perception of psycho-social school environment $(\mathrm{F}=6.452, \mathrm{p}<0.05)$, control dimension of perception of psycho-social school environment $(\mathrm{F}=5.261, \mathrm{p}<0.05)$, using resources dimension of personal growth initiative $(\mathrm{F}=5.954, \mathrm{p}<0.05)$, fears of experiencing shame and embarrassment dimension fear of failure $(\mathrm{F}=5.832, \mathrm{p}<0.05)$, fears of devaluing one's self-estimate dimension fear of failure $(\mathrm{F}=6.570, \mathrm{p}<0.05)$, fears of having an uncertain future dimension fear of failure $(\mathrm{F}=4.588, \mathrm{p}<0.05)$ and the dimension of fear of failure $(\mathrm{F}=4.947, \mathrm{p}<0.05)$.

Table 1 further indicated no significant difference between the students going to the college with EAMCET coaching and the students going to colleges without EAMCET coaching with respect to readiness for change dimension of personal growth initiative, Fears of Experiencing Shame and Embarrassment dimension of fear of failure, Fears-of Devaluing One's Self-Estimate dimension of fear of failure, Fears of Having an Uncertain Future dimension of fear of failure, Fears of Important Others Losing Interest dimensions of fear of failure, Fears of Upsetting Important Others dimension of fear of failure and dimension of fear of failure $(\mathrm{p}>0.05)$. Similarly No significant difference was observed between the boys and girls with respect to acceptance dimension of perception of psycho-social school environment, Fears of Experiencing Shame and Embarrassment dimension of fear of failure, Fears-of Devaluing One's Self-Estimate dimension of fear of failure, Fears of Having an Uncertain Future dimension of fear of failure, Fears of Important Others Losing Interest dimensions of fear of failure, Fears of Upsetting Important Others dimension of fear of failure and dimension of fear of failure $(p>0.05)$. 
As evident from the table 1 no significant interaction effect was observed with respect to Creative stimulation dimension of perception of psycho-social school environment, cognitive encouragement dimension of perception of psycho-social school environment, acceptance dimension of perception of psycho-social school environment and rejection dimension of perception of psycho-social school environment, Readiness for change dimension of personal growth initiative, planfulness dimension of personal growth initiative, intentional behaviour dimension of personal growth initiative, the dimension of personal growth initiative, Fears of Important Others Losing Interest dimension of fear of failure and Fears of Upsetting Important Others dimension of fear of failure ( $p>0.05)$.

Table $2 \mathrm{a}$ - The results of the Correlation between Perception of Psycho-social school environment in terms of its 6 dimensions; Personal growth initiative and its 4 dimensions and Fear of failure and its 5 dimensions in intermediate students (boys and girls) going to colleges with EAMCET coaching $(n=150)$.

\begin{tabular}{|c|c|c|c|c|c|c|c|c|c|c|c|}
\hline & $\begin{array}{c}\text { Creative } \\
\text { stimulation }\end{array}$ & $\begin{array}{c}\text { Cognitive } \\
\text { encouragement }\end{array}$ & Permissiveness & Acceptance & Rejection & Control & $\begin{array}{c}\text { Readiness for } \\
\text { change }\end{array}$ & Planfulness & $\begin{array}{c}\text { Using } \\
\text { resources }\end{array}$ & $\begin{array}{c}\text { Intentional } \\
\text { behavior }\end{array}$ & $\begin{array}{l}\text { personal growth } \\
\text { initiative }\end{array}$ \\
\hline Readiness for change & -.084 & .142 & -.066 & -.158 & -.131 & .041 & & & & & \\
\hline Planfulness & -.125 & .086 & -.097 & $-.207^{*}$ & $-.180^{*}$ & .091 & & & & & \\
\hline Using resources & $.222^{* *}$ & $.315^{* *}$ & $.256^{* *}$ & .080 & $-.324^{* *}$ & .125 & & & & & \\
\hline Intentional behavior & -.060 & .128 & -.001 & -.108 & -.103 & $.166^{*}$ & & & & & \\
\hline personal growth initiative & -.017 & $.198^{*}$ & .025 & -.120 & $-.219^{* *}$ & .128 & & & & & \\
\hline $\begin{array}{c}\text { Fears of experiencing } \\
\text { shame and embarrassment }\end{array}$ & -.156 & -.073 & -.098 & -.091 & -.040 & -.106 & $-.173^{*}$ & $-.178^{*}$ & -.063 & $-.175^{*}$ & $-.178^{*}$ \\
\hline $\begin{array}{l}\text { Fears of devaluing one's } \\
\text { self-estimate }\end{array}$ & $.165^{*}$ & .092 & $.234^{* *}$ & .140 & .011 & $.166^{*}$ & -.052 & -.074 & .082 & -.009 & -.017 \\
\hline $\begin{array}{l}\text { Fears of having an } \\
\text { uncertain future }\end{array}$ & .106 & .028 & $.213^{* *}$ & .051 & .062 & .048 & -.038 & -.072 & .047 & $-.188^{*}$ & -.079 \\
\hline $\begin{array}{c}\text { Fears of important others } \\
\text { losing interest }\end{array}$ & $-.265^{* *}$ & $-.193^{*}$ & $-.193^{*}$ & -.153 & .145 & -.036 & .043 & -.041 & -.111 & -.070 & -.055 \\
\hline $\begin{array}{l}\text { Fears of upsetting } \\
\text { important others }\end{array}$ & -.052 & -.131 & -.070 & -.026 & -.143 & -.058 & -.154 & -.085 & -.052 & $-.166^{*}$ & -.137 \\
\hline General fear of failure & -.070 & -.091 & .021 & -.030 & .016 & -.001 & -.113 & -.139 & -.034 & $-.193^{*}$ & -.146 \\
\hline
\end{tabular}

Table 2a reveals that there was a significant positive correlation between the creative stimulation dimension of perception of psycho-social school environment and the using resources dimension of personal growth initiative $(r=0.222, \mathrm{p}<0.01)$ and the Fears of devaluing one's self estimate dimension of fear of failure $(r=0.165, \mathrm{p}<0.05)$. In other words higher the perception by the students of their teachers as providing opportunities to stimulate creative thinking higher was the likelihood for ability to identify and access resources external to the self, such as other people and materials and the Fear of devaluing one's self estimate in intermediate students going to colleges with EAMCET coaching. Similarly a significant negative correlation was observed between the creative stimulation dimension of perception of psychosocial school environment and the fears of important others losing interest dimension of fear of failure $(r=-0.265, \mathrm{p}<0.01)$. In other words higher the perception by the students of their teachers as providing opportunities to stimulate creative thinking lower was the fear of important others losing interest in intermediate students going to colleges with EAMCET coaching.

Table $2 \mathrm{a}$ also indicated that there was a significant positive correlation between the cognitive encouragement dimension of perception of psycho-social school environment and the using resources 
dimension of personal growth initiative $(r=0.315, \mathrm{p}<0.01)$ and the dimension of personal growth initiative $(r=0.198, \mathrm{p}<0.05)$. In other words higher the perception by the students of their teacher's behaviour as stimulating cognitive development of students by encouraging their actions or behaviours higher was the likelihood for the ability to identify and access resources external to the self, such as other people and materials and active involvement in changing and developing as a person in intermediate students going to colleges with EAMCET coaching. Similarly there was a significant negative correlation between the cognitive encouragement dimension of perception of psycho-social school environment and the fears of upsetting important others dimension of fear of failure $(r=-0.193, \mathrm{p}<0.05)$. In other words higher the perception by the students of their teacher's behaviour as stimulating cognitive development of students by encouraging their actions or behaviours lower was the fear of upsetting important others in intermediate students going to colleges with EAMCET coaching.

Moreover table $2 \mathrm{a}$ also indicated that here was a significant positive correlation between the permissiveness dimension of perception of psycho-social school environment and the using resources dimension of personal growth initiative $(r=0.256, \mathrm{p}<0.01)$, the fears of devaluing one's self estimate dimension of fear of failure $(r=0.234, \mathrm{p}<0.01)$ and the fears of having an uncertain future dimension of fear of failure $(r=0.213, \mathrm{p}<0.01)$. In other words higher the perception by the students of their college as providing opportunities to express their views freely higher was the likelihood for the ability to identify and access resources external to the self, such as other people and materials, fear of devaluing one's self estimate and fear of having an uncertain future in intermediate students going to colleges with EAMCET coaching. Similarly there was a significant negative correlation between the permissiveness dimension of perception of psycho-social school environment and the fears of important others losing interest dimension of fear of failure $(r=-0.193, \mathrm{p}<0.05)$. In other words higher was the perception by the students of their college as providing opportunities to express their views freely lower was the fears of important others losing interest in intermediate students going to colleges with EAMCET coaching.

As was evident from table 2a there was a significant negative correlation between the acceptance dimension of perception of psycho-social school environment and the planfulness dimension of personal growth initiative $(r=-0.207, \mathrm{p}<0.05)$. In other words higher the perception by the students of their teachers as accepting their feelings in a non-threatening manner lower was the likelihood of the ability to be strategic and organized in self-change efforts in intermediate students going to colleges with EAMCET coaching.

Furthermore table $2 \mathrm{a}$ also showed that there was a significant negative correlation between the rejection dimension of perception of psycho-social school environment and the planfulness dimension of personal growth initiative $(r=-0.180, \mathrm{p}<0.05)$, the using resources dimension of personal growth initiative $(r=-0.324, \mathrm{p}<0.01)$ and the dimension of personal growth initiative $(r=-0.219, \mathrm{r}<0.01)$. In other words higher the perception by the students of their college in which the teachers do not accord recognition to student's right to deviate, act freely and be autonomous persons lower was the likelihood of the ability to be strategic and organized in self-change efforts, the ability to identify and access resources external to the self, such as other people and materials and active involvement in changing and developing as a person in intermediate students going to colleges with EAMCET coaching.

The results of table $2 \mathrm{a}$ also showed that there was a significant positive correlation between the control dimension of perception of psycho-social school environment and the intentional behaviour dimension of personal growth initiative $(r=0.166, \mathrm{p}<0.01)$ and the fears of devaluing one's self estimate dimension of fear of failure $(r=0.166, \mathrm{p}<0.01)$. In other words higher the perception by the students of their college as imposing several restrictions on the students to discipline them higher was the likelihood towards doing of self-change plans and behaviours and fear of devaluing one's self estimate in intermediate students going to colleges with EAMCET coaching. 
Moreover table 2a also shows that there was a significant negative correlation between the readiness for change dimension of personal growth initiative and the fears of experiencing shame and embarrassment dimension of fear of failure $(r=-0.173, \mathrm{p}<0.05)$. In other words higher was the ability to assess one's own psychological preparedness to engage in personal growth processes lower was the likelihood for the fear experiencing shame and embarrassment in intermediate students going to colleges with EAMCET coaching.

Furthermore table $2 \mathrm{a}$ also indicated that there was a significant negative correlation between the planfulness dimension of personal growth initiative and the fears of experiencing shame and embarrassment dimension of fear of failure $(r=-0.178, \mathrm{p}<0.05)$. In other words higher was the ability to be strategic and organized in self-change efforts lower was the likelihood for the fear experiencing shame and embarrassment in intermediate students going to colleges with EAMCET coaching.

The results of table $2 \mathrm{a}$ also suggested that there was a significant negative correlation between the intentional behaviour dimension of personal growth initiative and the fears of experiencing shame and embarrassment dimension of fear of failure $(r=-0.175, \mathrm{p}<0.05)$, the fears of having an uncertain future embarrassment dimension of fear of failure $(r=-0.188, \mathrm{p}<0.05)$; the fears of upsetting important others embarrassment dimension of fear of failure $(r=-0.166, \mathrm{p}<0.05)$ and the general fear of failure $(r=-0.193$, $\mathrm{p}<0.05$ ). In other words higher was the ability to identify and access resources external to the self, such as other people and materials lower was the likelihood of fear of experiencing shame and embarrassment, the fear of having an uncertain future embarrassment, the fear of upsetting important others and the general fear of failure in intermediate students going to colleges with EAMCET coaching.

Table $2 \mathrm{a}$ also revealed that there was a significant negative correlation between the dimension of personal growth initiative and the fears of experiencing shame and embarrassment dimension of fear of failure $(r=-0.178, \mathrm{p}<0.05)$. In other words higher the active involvement in changing and developing as a person lower was the likelihood of the fear of experiencing shame and embarrassment in intermediate students going to colleges with EAMCET coaching.

Table $2 \mathrm{~b}$ - The results of the Correlation between Perception of Psycho-social school environment in terms of its 6 dimensions; Personal growth initiative and its 4 dimensions and Fear of failure and its 5 dimensions in intermediate students (boys and girls) going to colleges without EAMCET coaching $(n=150)$. 


\begin{tabular}{|c|c|c|c|c|c|c|c|c|c|c|c|}
\hline & $\begin{array}{l}\text { Creative } \\
\text { stimulation }\end{array}$ & $\begin{array}{c}\text { Cognitive } \\
\text { encouragement }\end{array}$ & Permissiveness & Acceptance & Rejection & Control & $\begin{array}{l}\text { Readiness for } \\
\text { change }\end{array}$ & Planfulness & $\begin{array}{l}\text { Using } \\
\text { resources }\end{array}$ & $\begin{array}{l}\text { Intentional } \\
\text { behavior }\end{array}$ & $\begin{array}{c}\text { personal growth } \\
\text { initiative }\end{array}$ \\
\hline Readiness for change & .074 & $.311^{* *}$ & .106 & .036 & -.044 & .006 & & & & & \\
\hline Planfulness & .040 & $.217^{* *}$ & .121 & .011 & $-.200^{*}$ & .061 & & & & & \\
\hline Using resources & .057 & .116 & .033 & .100 & .046 & .009 & & & & & \\
\hline Intentional behavior & .118 & .130 & .041 & -.067 & -.031 & -.025 & & & & & \\
\hline personal growth initiative & .092 & $.246^{* *}$ & .094 & .028 & -.066 & .015 & & & & & \\
\hline $\begin{array}{c}\text { Fears of experiencing } \\
\text { shame and embarrassment }\end{array}$ & -.083 & .021 & -.126 & -.120 & .033 & .082 & .002 & .012 & -.085 & -.056 & -.041 \\
\hline $\begin{array}{l}\text { Fears of devaluing one's } \\
\text { self-estimate }\end{array}$ & -.039 & -.110 & .011 & .035 & .020 & .015 & -.036 & -.066 & -.137 & -.157 & -.125 \\
\hline $\begin{array}{l}\text { Fears of having an } \\
\text { uncertain future }\end{array}$ & -.093 & -.081 & -.104 & -.053 & .049 & .001 & -.073 & .018 & -.093 & -.093 & -.079 \\
\hline $\begin{array}{c}\text { Fears of important others } \\
\text { losing interest }\end{array}$ & .046 & .058 & .099 & $.215^{* *}$ & .009 & .041 & $.213^{* *}$ & .158 & -.024 & -.020 & .103 \\
\hline $\begin{array}{l}\text { Fears of upsetting } \\
\text { important others }\end{array}$ & -.137 & -.129 & $-206^{*}$ & -.122 & $.199^{*}$ & .049 & .142 & $.195^{*}$ & $.169^{*}$ & $.163^{*}$ & $.211^{* *}$ \\
\hline General fear of failure & -.091 & -.077 & -.093 & .001 & .097 & .056 & .086 & .105 & -.052 & -.051 & .026 \\
\hline
\end{tabular}

As shown in table $2 \mathrm{~b}$ there was a significant positive correlation between the cognitive encouragement dimension of perception of psycho-social school environment and the planfulness dimension of personal growth initiative $(r=0.217, \mathrm{p}<0.01)$, the readiness for change dimension of personal growth initiative $(r=0.311, \mathrm{p}<0.01)$ and the dimension of personal growth initiative $(r=0.246$, $\mathrm{p}<0.01)$. In other words higher the perception by the students of their teacher's behaviour as stimulating cognitive development of students by encouraging their actions or behaviours higher was the likelihood for the ability to be strategic and organized in self-change efforts, the ability to assess one's own psychological preparedness to engage in personal growth processes and the active involvement in changing and developing as a person in intermediate students going to colleges without EAMCET coaching.

The results of table $2 b$ reveal that there was a significant negative correlation between the permissiveness dimension of perception of psycho-social school environment and the fears of upsetting important others dimension of fear of failure $(r=-0.206, \mathrm{p}<0.05)$. In other words higher the perception by the students of their college as providing opportunities to express their views freely lower was the likelihood of fear of upsetting important others in intermediate students going to colleges without EAMCET coaching.

Moreover table $2 \mathrm{~b}$ also revealed that there was a significant positive correlation between the acceptance dimension of perception of psycho-social school environment and the fears of important others losing interest dimension of fear of failure $(r=0.215, \mathrm{p}<0.01)$. In other words higher the perception by the students of their teachers as accepting their feelings in a non threatening manner higher was the fears of important others losing interest in intermediate students going to colleges without EAMCET coaching. 
Furthermore table $2 \mathrm{~b}$ revealed that there was a significant positive correlation between the rejection dimension of perception of psycho-social school environment and the fears of upsetting important others dimension of fear of failure $(r=0.199, \mathrm{p}<0.05)$. In other words higher the perception by the students of their college in which the teachers do not accord recognition to student's right to deviate, act freely and be autonomous persons higher was the likelihood of the fear of upsetting important others in intermediate students going to colleges without EAMCET coaching. Similarly there was significant negative correlation between the rejection dimension of perception of psycho-social school environment and the planfullness dimension of personal growth initiative $(r=-0.200, \mathrm{p}<0.05)$. In other words higher the perception by the students of their college in which the teachers do not accord recognition to student's right to deviate, act freely and be autonomous persons lower was the likelihood for the ability to be strategic and organized in self-change efforts in intermediate students going to colleges without EAMCET coaching.

The results of table $2 \mathrm{~b}$ suggested that there was a significant positive correlation between the readiness for change dimension of personal growth initiative and the fears of important others losing interest dimension of fear of failure $(r=0.213, \mathrm{p}<0.01)$. In other words higher the ability to assess one's own psychological preparedness to engage in personal growth processes higher was the likelihood for the fear of important others losing interest in intermediate students going to colleges without EAMCET coaching.

Moreover the results of table $2 \mathrm{~b}$ also suggested that there was a significant positive correlation between the planfulness dimension of personal growth initiative and the dimension of fears of upsetting important others dimension of fear of failure $(r=0.195, \mathrm{p}<0.05)$. In other words higher the ability to be strategic and organized in self-change efforts higher was the likelihood for the fear of upsetting important others in intermediate students going to colleges without EAMCET coaching

Furthermore table $2 \mathrm{~b}$ also revealed that here was a significant positive correlation between the using resources dimension of personal growth initiative and the fears of upsetting important others dimension of fear of failure $(r=0.169, \mathrm{p}<0.05)$. In other words higher the ability to identify and access resources external to the self, such as other people and materials higher was the likelihood for the fear of upsetting important others in intermediate students going to colleges without EAMCET coaching.

Table $2 \mathrm{~b}$ also suggested that there was a significant positive correlation between the intentional behaviour dimension of personal growth initiative and the fears of upsetting important others dimension of fear of failure $(r=0.163, \mathrm{p}<0.05)$. In other words higher the likelihood towards doing of self-change plans and behaviours higher was the likelihood for and the fear of upsetting important others in intermediate students going to colleges without EAMCET coaching.

Furthermore table $2 \mathrm{~b}$ also suggested that there was a significant positive correlation between the dimension of personal growth initiative and the fears of upsetting important others dimension of fear of failure $(r=0.211, \mathrm{p}<0.01)$. In other words higher the active involvement in changing and developing as a person higher was the likelihood for the fear of upsetting important others in intermediate students going to colleges without EAMCET coaching. 


\section{DISCUSSION}

Psychosocial learning environment is one factor in Walberg's (1981) multi-factor psychological model of educational productivity, which holds that learning is a function of student's age, ability and motivation; of quality and quantity of instruction; and of the psychosocial environments of the home, the classroom, the peer group and the mass media (German \& Bloom, 1999).

The objective of the current research was to study whether there is a role of the type of college (viz. with EAMCET coaching and without EAMCET coaching) and gender perception of psychosocial school environment in terms of its 6 dimensions (viz., Creative stimulation, cognitive encouragement, acceptance, permissiveness, rejection and control), Personal growth initiative and its 4 dimensions (viz., Readiness for change, planfulness, using resources and intentional behaviour) and Fear of failure and its 5 dimensions (viz., Fears of Experiencing Shame and Embarrassment, Fears-of Devaluing One's SelfEstimate, Fears of Having an Uncertain Future, Fears of Important Others Losing Interest and Fears of Upsetting Important Others) in intermediate students. This study also aimed to study whether there is a relationship between the perception of school environment, personal growth initiative and fear of failure in intermediate students.

The present study reported that there is a significant difference between the students going to colleges with EAMCET coaching and the students going to colleges without EAMCET coaching with respect to the creative stimulation, the cognitive encouragement, permissiveness, acceptance, rejection and control dimension of perception of psycho-social school environment. The results indicated that the students especially the girls going to colleges without EAMCET coaching perceived their environment as providing opportunities to stimulate creative thinking, expressing their views freely and act according to their desires without any interruptions from the teachers, viewed their teachers as accepting the feelings of students in a non-threatening manner and viewed their college as imposing several restrictions on the students to discipline them. These results are partially supported by the findings of a previous study (Badola, 2013) which found that school climate is based on patterns of people's experiences of school life and reflected norms, goals, values, interpersonal relationship, teaching and learning practices and organizational structures. This study further stated that a sustainable, positive school climate fosters youth development and learning necessary of a productive, contributive and a satisfying life in a democratic society. Additionally Roeser, Midgley and Urdan (1996) reported that perceiving positive teacher-student relationships predicted positive school-related affect and this relation was mediated through feelings of school belonging.

The results also reported that students especially the boys going to colleges with EAMCET coaching viewed their college in which the teachers do not accord recognition to student's right to deviate, act freely and be autonomous persons. Research conducted by Skinner and Belmont (1993) concluded that when teachers are less involved with students, students not only miss the involvement but also experience teachers as less consistent and more coercive.

Accordingly, as it was hypothesized, the results show that there is a significant gender difference in students going to colleges with and without EAMCET coaching especially the girls going to colleges without coaching in terms of their ability to be strategic and organized in self-change effort, ability to identify and access resources external to the self, such as other people and materials, the students showed likelihood towards doing their self-change plans and behaviours and active involvement in changing and developing as a person. These findings are substantiated by Ayub \& Iqbal's (2012) study which found that adolescents high in personal growth initiative may be capable of looking forward to difficulties and keenly effort to avert the problems from happening than individuals low in personal growth initiative.

Furthermore, the findings of Robitschek and Keyes (2009) revealed that college students who are engaging in more intentional self-improvement (i.e., have relatively high levels of PGI), in comparison 
with their low-PGI peers, accept themselves more, have better relationships with others, see more purpose in life, perceive more control and mastery over their environment, and have a greater sense of autonomy or self-direction regarding their lives and daily choices. PGI has been defined as the degree to which individuals perceive themselves as being actively engaged in the change and growth process (Robitschek, 1998). He further reiterated that PGI is related to a "cognitive style associated with human agency."

On the other hand, the present study revealed no significant difference between students going to colleges with and without EAMCET coaching in terms of their ability to assess one's own psychological preparedness to engage in personal growth processes whereas significant gender differences were observed, in which the girls going to colleges with EAMCET coaching showed a higher likelihood towards readiness for change.

No significant gender differences were observed in students going to colleges with and without EAMCET coaching in terms of Fears of Experiencing Shame and Embarrassment, Fears-of Devaluing One's Self-Estimate, Fears of Having an Uncertain Future, Fears of Important Others Losing Interest, Fears of Upsetting Important Others and general fear of failure. The findings of the research are not in accordance with the findings of Mulig et al. (1985) that fear of success was found to be a sex-role-related construct whereas fear of failure was found to be a gender-related construct.

Furthermore, the results show that higher the perception by the students of their teachers as providing opportunities to stimulate creative thinking higher is the likelihood for ability to identify and access resources external to the self, such as other people and materials and lower is the fear of important others losing interest in intermediate students going to colleges with EAMCET coaching. Results also showed no significant relationship the dimensions of personal growth initiative and fear of failure in students going to colleges without EAMCET coaching. The results are in accordance with Rao et al. (2009) that it is incumbent upon the teacher to create an environment which encourages learning, the teacher must use teaching methods that will make the lesson interesting and encourage student's critical thinking and creativity.

Accordingly, as it was hypothesized that higher the perception by the students of their teacher's behaviour as stimulating cognitive development of students by encouraging their actions or behaviours higher is the likelihood for the ability to identify and access resources external to the self, such as other people and materials and active involvement in changing and developing as a person and lower is the fear of upsetting important others in intermediate students going to colleges with EAMCET coaching. Conceptual learning within the subject needs to be approached through encouraging student involvement (Rao et al., 2009).

The results also indicated a significant positive correlation between the cognitive encouragement dimension of perception of psycho-social school environment and the ability of the student to be strategic and organized in self-change efforts, the ability to assess one's own psychological preparedness to engage in personal growth processes and the active involvement in changing and developing as a person in intermediate students going to colleges without EAMCET coaching. The finding by Knapp et al. (1995) was the most consistent that teachers who emphasized higher-order thinking, either through the questions they asked or the tasks they assigned, promoted greater reading growth among the target students in their classrooms. They further posited that this extra emphasis on higher-level thinking increased students' understanding of what they were doing and encouraged them to be meaning makers.

Moreover, a significant positive correlation was found between the permissiveness dimension of perception of psycho-social school environment and the using resources dimension of personal growth initiative, the fears of devaluing one's self estimate and the fears of having an uncertain future, dimensions of fear of failure. Similarly a significant negative correlation was observed with the fears of important others losing interest dimension of fear of failure. It can also be understood as higher the 
perception by the students of their college as providing opportunities to express their views freely higher is the likelihood for the ability to identify and access resources external to the self, such as other people and materials, fear of devaluing one's self estimate and fear of having an uncertain future and lower is the fears of important others losing interest in intermediate students going to colleges with EAMCET coaching.

Among the students going to colleges with EAMCET coaching results indicate that higher the perception by the students of their teachers as accepting their feelings in a non-threatening manner lower is the likelihood of the ability to be strategic and organized in self-change efforts. And higher is the fears of important others losing interest in intermediate students going to colleges without EAMCET coaching.

As is evident from the results there is a significant negative correlation between the rejection dimension of perception of psycho-social school environment and planfulness, the using resources and the dimension of personal growth initiative in intermediate students going to colleges with EAMCET coaching. In other words, in students going to colleges without EAMCET coaching, more favourable the perception of the college by the students in which the teachers do not accord recognition to student's right to deviate, act freely and be autonomous persons, higher is the likelihood of the fear of upsetting important others and lower is the likelihood for the ability to be strategic and organized in self-change efforts.

As hypothesized, a significant positive correlation was observed between the control dimension of perception of psycho-social school environment and the intentional behaviour dimension of personal growth initiative and the fears of devaluing one's self estimate dimension of fear of failure. It can also be understood as higher the perception by the students of their college as imposing several restrictions on the students to discipline them higher is the likelihood towards doing of self-change plans and behaviours and fear of devaluing one's self estimate in intermediate students going to colleges with EAMCET coaching. According to Roeser, Midgley and Urdan (1996) perceiving positive teacher-student relationships predicted positive school-related affect and this relation was mediated through feelings of school belonging by the students.

Results also indicated that higher is the ability to assess one's own psychological preparedness to engage in personal growth processes, the ability to be strategic and organized in self-change efforts and the active involvement in changing and developing as a person lower is the likelihood of the fear of experiencing shame and embarrassment in intermediate students going to colleges with EAMCET coaching. Teacher's involvement with individual students had the most powerful impact on children's perceptions of the teacher (Skinnker and Belmont, 1993). On the other hand, in students going to colleges without EAMCET coaching a significant positive correlation was observed between the readiness for change dimension of personal growth initiative and the fears of important others losing interest dimension of fear of failure which can be reiterated as higher the ability to assess one's own psychological preparedness to engage in personal growth processes higher is the likelihood for the fear of important others losing interest.

Likewise as hypothesized, a significant positive correlation was observed between the planfulness dimension of personal growth initiative, using resources dimension of personal growth initiative, intentional behaviour dimension of personal growth initiative, dimension of personal growth initiative and the dimension of fears of upsetting important others dimension of fear of failure. In other words, higher the ability to be strategic and organized in self-change efforts, ability to identify and access resources external to the self, such as other people and materials, doing of self-change plans and behaviours, active involvement in changing and developing as a person higher is the likelihood for the fear of upsetting important others in intermediate students going to colleges without EAMCET coaching. 
There is a significant negative correlation between the intentional behaviour dimension of personal growth initiative and the fears of experiencing shame and embarrassment dimension of fear of failure, the fears of having an uncertain future embarrassment dimension of fear of failure, the fears of upsetting important others embarrassment dimension of fear of failure and the general fear of failure. It can also be understood as higher is the ability to identify and access resources external to the self, such as other people and materials lower is the likelihood of fear of experiencing shame and embarrassment, the fear of having an uncertain future embarrassment, the fear of upsetting important others and the general fear of failure in intermediate students going to colleges with EAMCET coaching. In a recent study, Puca and Schmalt (2001) found that failure-motivated individuals showed a drop in success-related thoughts and an increase in failure-related thoughts just after they had decided on which of the two task to work on. And also according to Heckhausen et. al., (1985) individuals high in fear of failure often expect to fail at the pursuit of goals they desire to attain.

\section{Conclusion}

One of the limitations of the current study is that it did not take into account the student's home environment, which according to Muola, (2010) refers to the objects, forces and conditions in the home which influence the child physically, intellectually and emotionally. The parent's level of education, economic status, occupational status, religious background, attitudes, values, interests, parent's expectation for their children, and family size among others are a few aspects of the home environments that affect the children.

The current study concludes that there is a significant gender differences between the intermediate students going to colleges with and without EAMCET coaching with respect to their perception of psycho-social school environment, personal growth initiative and fear of failure. The study also concluded significant relationship between perception of psycho-social school environment, personal growth initiative and fear of failure. The results of the current study highlight the need for higher education personnel and administrators of the special coaching institutions to adopt a syllabus which enhances the student's understanding of the core subjects in a way that will improve their personal growth initiative. Furthermore, mental health professionals could help in reducing fear of failure and improve confidence especially in intermediate students appearing for competitive examinations.

\section{REFRENCES}

Axelton, K. (1998). Bouncing back. Entrepreneur Magazine, Retrieved March, 2011. http://www.Entrepreneur.com

Ayub, N., \& Iqbal, S. (2012). The relationship of personal growth initiative, psychological well-being, and psychological distress among adolescents. Journal of Teaching and Education, 1(6), 101-107.

Badola, S. (2013). A study of home climate and school environment of senior secondary school student in relation to their decision maturity. Educationia Confab, 2(4), 62-67.

Bandura, A. (2001). Social cognitive theory: An agentic perspective. Annual Review of Psychology, 52, $1-26$

Berger, S., \& Freund, A. M. (2012). Fear of failure, disorganization, and subjective well-being in the context of preparing for an exam. Swiss Journal of Psychology.

Cobb, N. J. (1995). Adolescence: Continutity, change, and diversity. Mountain View CA: Mayfield Publishing Company.

Conroy, D. E., \& Metzler, J. N. (2003). Temporal stability of performance failure appraisal inventory items. Measurement in Physical Education and Exercise Science, 7(4), 243-261. 
Conroy, D.E., Willow, J.P., \& Metzler, J.N. (2002). Multidimensional fear of failure measurement: The performance failure appraisal inventory. Journal of Applied Sport Psychology, 14, 76-90.

Covington, M. V. (1984). The self-worth theory of achievement motivation: Findings and implications. The Elementary School Journal, 85(1), 5-20.

Diller, B. (1995). The discomfort zone (learning from failure in business). Inc, 17(16), 19-21.

Dorman, J., \& Fraser, B. (2009). Psychosocial environment and affective outcomes in technology-rich classrooms: testing a causal model. Social Psychology of Education, 12, 77-99.

Durant, N., Harris, S. K., Doyle, S., Person, S., Saelens, B. E., Kerr, J., .. \& Sallis, J. F. (2009). Relation of School Environment and Policy to Adolescent Physical Activity. Journal of School Health, 79(4), 153-159.

Eccles, J. S., \& Midgley, C. (1989). Stage-environment fit: Developmentally appropriate classrooms for young adolescents. Research on motivation in education, 3, 139-186.

Elliot, A. J., \& Thrash, T. M. (2004). The intergenerational transmission of fear of failure. Personality and Social Psychology Bulletin, 30(8), 957-971.

German, C.B., \& Bloom, M. (1999). Human behaviour in the social environment. An ecological view (2 ${ }^{\text {nd }}$ edition). New York: Colimbia University Press.

Haapasalo, I., Välimaa, R., \& Kannas, L. (2010). How comprehensive school students perceive their psychosocial school environment. Scandinavian Journal of Educational Research, 54(2), 133-150.

Heckhausen, H. (1991). Motivation and action. New York: Springer

Heckhausen, H., Schmalt, H.-D., \& Schneider, K. (1985). Achievement motivation in perspective. New York: Academic Press.

Kenny, D. T., \& Faunce, G. (2004). Effects of academic coaching on elementary and secondary school students. The Journal of Educational Research, 98(2), 115-126.

Knapp, M. S., Adelman, N. E., Marder, C., McCollum, H., Needels, M. C., Padilla, C., Shields, P. M., Turnbull, B. J., \& Zucker, A. A. (1995). Teaching for meaning in high-poverty classrooms.New York: Teachers College Press.

Kousalya, P., Ravindranath, V., \& Vizayakumar, K. (2006). Student absenteeism in engineering colleges: Evaluation of alternatives using AHP.Advances in Decision Sciences, 2006.

Lerner, R. M., Lerner, J. V., Almerigi, J. B., Theokas, C., Phelps, E., Gestsdottir, S., ... \& Smith, L. M. (2005). Positive Youth Development, Participation in community youth development programs, and community contributions of fifth-grade adolescents findings from the first wave Of the 4-H study of Positive Youth Development. The Journal of Early Adolescence,25(1), 17-71.

Lewin, K. (1935). A dynamic theory of personality. New York: McGraw-Hill.

Luiselli, J. K., Putnam, R. F., Handler, M. W., \& Feinberg, A. B. (2005). Whole-school positive behaviour support: effects on student discipline problems and academic performance. Educational Psychology, 25(2-3), 183-198. 
Maehr, M. L. (1991). The "psychological environment" of the school: A focus for school leadership. In P. Thurstone \& P. Zodhiates (Eds.), Advances in educational administration (Vol. 2, pp. 51-81). Greenwich, CT: JAI Press.

Mayya, S., \& Roff, S. (2004). Students' perceptions of educational environment: a comparison of academic achievers and under-achievers at Kasturba Medical College, India. Education For HealthAbingdon-Carfax Publishing Limited, 17, 280-291.

Midgley, C., Feldlaufer, H., \& Eccles, J. S. (1989). Student/teacher relations and attitudes toward mathematics before and after the transition to junior high school. Child development, 981-992.

Misra, K.S. (1984). Manual for School Environment Inventory. National Psychological Corporation, Agra.

Mulig, J. C., Haggerty, M. E., Carballosa, A. B., Cinnick, W. J., \& Madden, J. M. (1985). Relationships among fear of success, fear of failure, and androgyny. Psychology of women quarterly, 9(2), 284287.

Muola, J. M. (2010). A study of the relationship between academic achievement motivation and home environment among standard eight pupils.Educational research and reviews, 5(5), 213.

Prochaska , J. O . and DiClemente . C . C . (1986) Toward a comprehensiv e mode 1 o f change . In Miller , W. R. and Heather . N . (eds) . Treating Addictive Behaviors'. Processes of Change. Plenum , Ne w York, pp . 3-27.

Puca, R.M., \& Schmalt, H.-D. (2001). The influence of the achievement motive on spontaneous thoughts in pre- and postdecisional action phases. Personality and Social Psychology Bulletin, 27, 302-308.

Rao, B. V., Vijayawada, A. P., LAKSHMI, I. D. S., \& Mylavaram, K. D. (2009). REFLECTIVE APPROACH IN TEACHING PRE-DEGREE CHEMISTRY. Turkish Online Journal of Distance Education (TOJDE), 10(2).

Robitschek, C. (1998). Personal growth initiative: The construct and its measure. Measurement and Evaluation in Counseling and Development, 30, 183-198.

Robitschek, C., \& Keyes, C. L. (2009). Keyes's model of mental health with personal growth initiative as a parsimonious predictor. Journal of Counseling Psychology, 56(2), 321.

Robitschek, C., Ashton, M. W., Spering, C. C., Geiger, N., Byers, D., Schotts, G. C., \& Thoen, M. A. (2012). Development and psychometric evaluation of the Personal Growth Initiative ScaleII. Journal of Counseling Psychology, 59(2), 274.

Robitschek, C., Ashton, M. W., Spering, C. C., Martinez, M., Shotts, G. C., \& Murray, D. (2009, June). Development of the Personal Growth Initiative Scale-II. In Poster presented at the 2009 World Congress on Positive Psychology, Philadelphia, PA.

Roeser, R. W., Midgley, C., \& Urdan, T. C. (1996). Perceptions of the school psychological environment and early adolescents' psychological and behavioral functioning in school: The mediating role of goals and belonging.Journal of educational psychology, 88(3), 408.

Sagar C.J. and Kaplan, H.S. (1972). Progress in group and family therapy, New York: Brunner Mazel.

Selberg, G. (2001) Främja elevers lärande genom elevinflytande, Lund: Studentlitteratur. 
Sharma, H. L., \& Rani, R. (2013). Relationship of personal growth initiative with self-efficacy among university postgraduate students. Journal of Education and Practice, 4(16), 125-134.

Sharma, R. (2011). Effect of school and home environments on creativity of children. MIER Journal of Educational Studies, Trends and Practices, 1(2).

Singh, V. (1977). Some theoretical and methodological problems in the study of ethnic identity: A crosscultural perspective. New York Academy of 5ciences: Annals, 222, 32-42.

Skinnker, E. \& Belmont, M. (1993) Motivation in the classroom: Reciprocal Effects of Teacher Behaviour and student engagement across the school year. Journal of Educational Psychology, 85, 571-581.

Verma, S., Sharma, D., \& Larson, R. W. (2002). School stress in India: Effects on time and daily emotions. International Journal of Behavioral Development, 26(6), 500-508.

Walberg, H. (1991). Classroom psychological environment. In K. Majoribanks (Ed.), The Foundations of Student Learning. New York: Pergamon.

Walberg, H. J. (1981). A psychological theory of educational productivity. In F. H. Farley, \& N. Gordon (Eds.), Psychology and education (pp. 81-110). : Chicago7 National Society for the Study of Education.

Wigfield, A., Byrnes, J. P., \& Eccles, J. S. (2006). Development during early and middle adolescence. Handbook of educational psychology, 2, 87-113.

Wubbels, T. (2005). Editorial: Student perceptions of teacher-student relationships in class. International Journal of Educational Research 43, 1-5. 